Katarzyna Kocot-Górecka

Instytut Statystyki i Demografii

Szkoła Główna Handlowa

kkocot@sgh.waw.pl

\title{
SPOŁECZNO-DEMOGRAFICZNE PREDYKTORY POGLĄDÓW KOBIET I MĘŻCZYZN DOTYCZĄCYCH KULTUROWYCH RÓL PŁCI W POLSCE ${ }^{1}$
}

\section{WPROWADZENIE}

Zmiany niektórych zachowań demograficznych dotyczących rodziny związane z drugim przejściem demograficznym pojawiły się w Polsce jeszcze przed 1989 rokiem. Przede wszystkim dotyczyło to spadku płodności, która w miastach już od drugiej połowy lat 1960-tych nie gwarantowała prostej zastępowalności pokoleń. Przełom lat 1970-tych i 1980-tych przyniósł niewielki wzrost płodności, ale w latach następnych nastąpił powrót do trendu spadkowego. Jednak w latach 1990tych tempo obniżania się współczynników dzietności w całym kraju zwiększyło się. W tym samym czasie pojawił się również wyraźny wzrost liczby rozwodów, spadała liczba zawieranych małżeństw mimo tego, że rosła liczba osób w wieku 20-29 lat i coraz częściej rodziny tworzone były przez pary pozostające w kohabitacji. Przyczyn nowych zjawisk demograficznych w Polsce, a także w innych krajach Europy Środkowo-Wschodniej zaczęto doszukiwać się w zmianie warunków uczestnictwa na rynku pracy, w tym zagrożenia bezrobociem i rosnącej niepewności zatrudnienia, jak również w ograniczeniu funkcji opiekuńczej państwa (Kotowska 1999, Frejka 2008, Kotowska 2009).

Zmiany procesu formowania i rozwoju rodziny w krajach tego regionu są również przypisywane przenoszeniu wzorców zachowań występujących w Europie Zachodniej określanym za Caldwellem (1976) jako westernizacja (Kotowska 1999, Frejka 2008, Sobotka 2004, Kotowska i inni 2008, Lesthaeghe i Surkyn 2002). W Europie

1 Autorka bardzo dziękuje Profesor Irenie E. Kotowskiej za cenne uwagi w trakcie realizacji badań oraz przy opracowywaniu niniejszego artykułu. 
Zachodniej spadek dzietności do poziomu poniżej prostej zastępowalności pokoleń, wzrost częstości rozwodów oraz rozpowszechnienie się różnych form tworzenia rodziny rozpoczęły się już w latach 1960 -tych. W poszukiwaniu ich przyczyn twórcy teorii drugiego przejścia demograficznego (van de Kaa i Lesthaeghe 1986) przypisują wiodącą role czynnikom światopoglądowym, w tym zasadniczym zmianom wartości, norm i postaw społecznych. Przejawiają się one wzrostem autonomii jednostki, równości społecznej, tolerancji i indywidualizmu (Lesthaeghe i Surkyn 1988). Wynikiem liberalizacji było, między innymi, stopniowe przekształcanie kulturowych ról płci (gender) w kierunku ich coraz większego egalitaryzmu (Fischer i Hout 2006, Jackson 1998, Thornton i Young-DeMarco 2001).

Do rozważań dotyczących zachowań demograficznych koncepcję gender system, czyli systemu społecznych zależności płci, wprowadziła Mason (1995). Rozwijając tę ideę, McDonald (2000a, 2000b), przedstawił koncepcję równości płci i jej wpływu na płodność oraz formowanie i rozwój rodziny. Rozpatrywał równość płci w dwóch wymiarach: równość płci w instytucjach zorientowanych na jednostkę (przede wszystkim rynek pracy i edukacja) oraz w instytucjach zorientowanych na rodzinę i w samej rodzinie. Rozważając zależność między płodnością a tymi dwoma kategoriami równości płci, McDonald sformułował hipotezę, że bardzo niska płodność jest wynikiem dysproporcji pomiędzy stosunkowo większym zaawansowaniem zmian dotyczących równości płci w instytucjach ukierunkowanych na jednostkę i względnie niskim postępem zmian w zakresie równości płci w instytucjach zorientowanych na rodzinę i w samej rodzinie. Koncepcja McDonalda wprowadziła na stałe kulturowe role płci do teoretycznych i empirycznych badań nad uwarunkowaniami płodności w krajach rozwiniętych, choć wcześniej znaczenie kulturowych ról kobiet i mężczyzn było podejmowanie w pracach demografów (np. Rindfuss, Brewster i Kavee 1996), zwłaszcza w kontekście wzajemnych powiązań między płodnością i aktywnością ekonomiczną kobiet (Liefbroer i Corijn 1999). W licznych publikacjach rozpatrujących te powiązania zarówno na poziomie makro jak i w skali mikro czynione są odwołania do kontekstu obejmującego rozwiązania instytucjonalne, struktur rynku pracy oraz percepcji ról społecznych kobiet i mężczyzn (np. Engelhardt, Kogel i Prskawetz 2004, Kotowska 2005, 2009, Muszyńska 2007, Oláh i Bernhardt 2008, Matysiak 2011, 2012). Także w pracach traktujących o uwarunkowaniach niskiej dzietności kontekst, w tym zmiany społecznych ról płci, są stale przywoływane zarówno w odniesieniu do zachowań prokreacyjnych jak i planów rodzicielskich (np. Rindfuss, Guzzo i Morgan 2003, Kohler, Billari i Ortega 2006, Muszyńska 2007, Prskawetz, Mamolo i Engelhardt 2010, Goldscheider, Oláh i Puur 2010, Matysiak 2012, Neyer, Lappergard i Vignoli 2011, Mynarska, Styrc 2014).

Szereg zmian społeczno-demograficznych w Polsce, które miały miejsce w ostatnich dwóch dekadach, mogło dodatkowo przyczynić się do zwiększenia zróżnicowania postaw wobec równości płci. Szczególnie ze względu na trudną sytuację na rynku pracy różnice w możliwościach planowania i realizowania kariery zawo- 
dowej i rodzinnej przez osoby różnej płci, w różnym wieku, o różnym poziomie wykształcenia i miejscu zamieszkania mogą kształtować w odmienny sposób te postawy. W artykule podjęto próbę znalezienia istotnych predyktorów postaw kobiet i mężczyzn wobec kulturowych ról płci na podstawie danych badania ankietowego „Generacje, Rodziny i Płeć Kulturowa” (GGS-PL-1) zrealizowanego w Polsce na przełomie 2010 i 2011 roku. Zestaw analizowanych cech został poszerzony o charakterystyki domu rodzinnego, które w tak zmieniającej się rzeczywistości mogły również zmienić swoje znaczenie dla postaw osób na początku drugiej dekady XXI wieku. Po krótkim wprowadzeniu do przedmiotu rozważań przedstawione jest podejście analityczne do analiz kulturowych ról płci: operacjonalizacja postaw wobec równości płci, wykorzystane dane oraz metody analizy. Następnie dyskutowane są kolejno wyniki analiz opisowych oraz analiz modelowych. Podsumowanie wyników analiz empirycznych i sugestie dalszych badań kończą artykuł.

\section{CZYNNIKI KSZTAŁTUJĄCE KULTUROWE ROLE PŁCI}

Kulturowe role płci wyrażają różnice społeczno-kulturowe między kobietami i mężczyznami wynikające z przypisywania jednostkom różnych rodzajów aktywności uznanych za potrzebne dla życia społecznego na podstawie płci biologicznej. Również według płci przypisywane są cechy osobowościowe jednostek uzasadniające ich aktywność. W ten sposób utrwalają się nie tylko pewne wzorce męskości i kobiecości, które wpływają na ocenianie przydatności jednostek do aktywności zawodowej, rodzinnej i społecznej, ale także kształtują się postawy wobec ról pełnionych przez kobiety i mężczyzn zarówno w sferze prywatnej jak i publicznej. Ta niejednakowa sytuacja kobiet i mężczyzn tworzy w społeczeństwie dysproporcje płci w dostępie do zasobów, siły i prestiżu (Mason 1995).

Aronson (1997) definiuje postawę jako trwałą ocenę (pozytywna lub negatywna) ludzi, obiektów i idei, na którą składają się trzy komponenty: emocjonalny - reakcje emocjonalne wobec przedmiotu postawy; poznawczy - myśli i przekonania o przedmiocie postawy oraz behawioralny - działania (zachowanie) wobec przedmiotu postawy. W tym artykule skupiamy się na jednym komponencie postaw wobec kulturowych ról płci tzn. na poglądach dotyczących tych ról.

Postawy społeczne kształtują się pod wpływem różnych czynników społeczno-kulturowych. Według Mądrzyckiego (1997) są to: wpływ kultury, grup społecznych, wiedza, płeć i wiek. Ważnym czynnikiem wpływającym na kształtowanie się postaw jest edukacja. Zdobywana wiedza sprzyja wypieraniu uprzedzeń i przesądów oraz kształtowaniu się tolerancji. Na ten proces wpływa także płeć poprzez stosowanie odrębnych metod wychowania zgodnych z panującymi wzorcami kulturowych ról płci.

Jednocześnie należy podkreślić, że wykształcenie odgrywa szczególną rolę wśród kobiet, bowiem stanowi stymulantę ich aktywności zawodowej. Posiadając wysokie umiejętności zawodowe, mają one większe możliwości korzystania z równego 
traktowania w miejscu pracy, a jednocześnie - mając wysokie aspiracje wynikające z wykształcenia - mogą bardziej odczuwać skutki nierównego traktowania.

Postawy wobec kulturowych ról płci mogą ulegać zmianom w przebiegu życia. $\mathrm{W}$ ich kształtowaniu ważny jest okres dzieciństwa. W procesie wychowawczym przyswajane są bowiem zasady organizujące życie społeczne przekazywane przez rodzinę i dalsze otoczenie. W okresie młodości jednostka stosunkowo łatwo przyswaja nowe wartości. Wraz z wiekiem jednostka doświadcza coraz więcej nowych zadań, kontaktuje się z nowymi osobami i grupami społecznymi i pod ich wpływem również może zmieniać swoje postawy.

Postawy jednostek wobec kulturowych ról płci zmieniają się bardzo powoli (Inglehart, Norris 2009). W pewnych okolicznościach proces ten może być szybszy. Na przykład H.Eysenck i M.Eysenck (1998) głoszą, że gdy okoliczności zmuszają do zmiany własnych zachowań, powstaje potrzeba wytłumaczenia ich przed samym sobą. Sprzyjającymi do tego warunkami mogą się stać trudności w znalezieniu pracy, zorganizowaniu opieki nad dzieckiem, konieczności pracy obojga partnerów i nowego podziału obowiązków domowych. Są to trudności, które przede wszystkim dotykają młodsze pokolenia. W związku z tym wśród starszych zmiany postaw mogą następować wolniej i utrwalone stereotypy na temat kulturowych ról płci są wyraźniejsze.

Przyczynami powstawania różnic postaw wobec kulturowych ról płci pomiędzy młodszymi i starszymi pokoleniami są odmienne warunki dorastania i formowania własnej kariery rodzinnej i zawodowej w różnych okresach historycznych. Inglehart (1989) twierdzi, że kohorty, które dorastały po II wojnie światowej w okresie gospodarczego wzrostu, szerzej przyswoiły egalitarne wartości. Inglehart i Norris (2003) udowodnili też, że przynależność do generacji silniej wpływa na postawy niż płeć, klasa społeczna czy edukacja.

Ewolucji kulturowych ról płci w krajach europejskich w kierunku coraz większego równouprawnienia towarzyszy rozpowszechnianie się ekonomicznego modelu rodziny, w którym zarówno mężczyzna jak i kobieta pracują zawodowo (dual earner family). Tym samym dla wielu kobiet dostarczanie środków na utrzymanie rodziny (rola żywiciela rodziny) i realizowanie się w pracy zawodowej stały się częścią ich tożsamości (Goldin 2006). Jednak zarówno rozwiązania instytucjonalne nakierowane na jednostkę jak i rozwiązania nastawione na rodzinę nie są dostosowane do tej nowej roli kobiet, podobnie jak zmiany podziału zobowiązań w rodzinie, generując tzw. konflikt strukturalny i konflikt kulturowy (Liefbroer i Corijn 1999, Muszyńska 2007; Kotowska 2005, 2009; Matysiak 2006, 2011). Zmiany w kierunku równości płci są bardziej zaawansowane w sferze publicznej niż w prywatnej (Mc Donald 2000a), bowiem zmiany postaw wobec ról pełnionych w rodzinie przebiegają znacznie wolniej (Blossfeld i Drobnic 2001). Skala tego niedostosowania wpływa na zakres obciążeń kobiet, które $\mathrm{z}$ jednej strony mają obowiązki zawodowe jak mężczyźni, z drugiej zaś - zobowiązania rodzinne w stopniu większym niż mężczyźni. Stąd praktykowany model rodziny to na ogół 
model z podwójnym obciążeniem kobiet (dual earner - double burden of women) (Matysiak 2006, Kotowska 2005, 2009).

W Polsce występuje brak równowagi w równouprawnieniu płci w sferze publicznej i prywatnej (Muszyńska 2007). Na początku lat 1990-tych Polska była postrzegana jako kraj katolicki z powszechnym tradycyjnym podejściem do roli kobiet, w którym jednak istniał utrwalony przez lata komunistycznego systemu wizerunek kobiety pracującej zawodowo. W pierwszych latach gospodarki rynkowej konflikt ról płci dodatkowo się nasilił. Po pierwsze, zmiany na rynku pracy wymusiły większe zaangażowanie $\mathrm{w}$ znalezienie i utrzymanie zatrudnienia. Po drugie, istniejące trudności na rynku pracy i bezrobocie sprzyjały wyrażaniu opinii, że przy niedoborze miejsc pracy to zatrudnienie mężczyzn powinno być preferowane. Pojawiło się postrzeganie kobiet jako konkurujących z mężczyznami o miejsca pracy. W dodatku malejąca dzietność sprawiła, że równouprawnienie kobiet oraz ich obowiązki wobec dzieci i tym samym wobec przyszłego pokolenia stały się częstym tematem dyskusji publicznych, w których dość mocno wyrażano poglądy o podporząakowaniu pracy zawodowej kobiet ich roli w rodzinie, czyli preferowaniu modelu rodziny określanego jako 'modernised breadwinner model' (Kotowska 2005; Matysiak 2006). W następnej dekadzie w dalszym ciągu do tych kwestii nawiązuje część mediów i ugrupowań politycznych, choć coraz silniej zaznacza się wątek równego traktowania kobiet i mężczyzn. W ostatnich latach obserwujemy coraz więcej działań zmierzających do zwiększenia równouprawnienia płci zarówno w sferze publicznej jak i prywatnej sferach (np. wprowadzenie urlopów ojcowskich i rodzicielskich, programy i akcje w mediach dotyczące równego traktowania kobiet i mężczyzn w miejscu pracy, promocję zaangażowania ojców w opiekę nad dziećmi, działalność organizacji pozarządowych), a także rosnący udział mężczyzn w obowiązkach domowych i opiekuńczych.

Ogólnie pojęcie nowoczesnej postawy wobec kulturowych ról płci oznacza akceptację równouprawnienia kobiet i mężczyzn zarówno w sferze publicznej jak i prywatnej. Tradycyjna postawa wiąże się z brakiem takiej akceptacji. Jednak stopień aprobaty zrównania praw i obowiązków obu płci nie musi być identyczny w każdej sferze życia. Akceptacja równouprawnienia płci w pracy nie oznacza takiej samej postawy wobec równości płci w rodzinie, czy popierania równego udziału kobiet w strukturach rządowych (Philipov 2008).

W niniejszym artykule do oceny postaw wobec równości płci w społeczeństwie polskim posłużyły dane pochodzące z panelowego badania ankietowego „, Generacje, Rodziny i Płeć Kulturowa" (GGS-PL-1), którego pierwsza runda zrealizowana była w Polsce na przełomie lat 2010 i 2011. Bliższe informacje o tym badaniu można znaleźć w tekście Kotowskiej i Jóźwiak (2011). Do konstruowania zmiennych charakteryzujących postawy respondentów wykorzystano zawarte w nim informacje o ich poglądach na temat kulturowych ról płci.

Celem analizy empirycznej była ocena predyktorów poglądów na temat kulturowych ról płci wśród kobiet i mężczyzn urodzonych w latach 1950-1989 w Polsce. 
Szczególne istotnym wyznacznikiem tych postaw wydają się dom rodzinny i indywidualne cechy społeczno-demograficzne.

Odpowiedzi na pytania dotyczące opinii o równości płci w sferze publicznej oraz w związku pomiędzy partnerami/współmałżonkami wykazały dużą zbieżność. To stanowiło przesłankę opisania tych odpowiedzi łącznie za pomocą jednej zmiennej syntetycznej, która charakteryzuje poglądy respondentów dotyczące sfery publicznej oraz związku. Dalej będzie stosowane określenie 'poglądy respondentów dotyczące sfery społecznej'. Natomiast rozkłady odpowiedzi na pytania dotyczące roli matki i ojca w rodzinie wyraźnie się różniły od pozostałych. Te odpowiedzi opisano łącznie za pomocą drugiej zmiennej syntetycznej, która dotyczy poglądów na temat odpowiedzialności za dziecko. Skonstruowano zatem dwie syntetyczne zmienne charakteryzujące poglądy respondentów wobec równości płci w sferze społecznej i sferze prywatnej, czyli opisujące postawy respondentów wobec równości płci.

Analizy empiryczne są podporządkowane weryfikacji dwóch hipotez badawczych odnoszących się do wyodrębnionych sfer:

H1: Istotnymi predyktorami poglądów kobiet i mężczyzn wobec równości płci w sferze społecznej oraz sferze odpowiedzialności za dziecko są: aktywność zawodowa, wykształcenie, miejsce zamieszkania, liczba dzieci oraz religijność.

H2: Cechy domu rodzinnego są istotnymi predyktorami poglądów kobiet i mężczyzn wobec równości płci $\mathrm{w}$ sferze społecznej oraz sferze odpowiedzialności za dziecko.

\section{DANE I METODA}

Wyznaczenie cech jednostkowych oraz cech domu rodzinnego, które mogą wpływać na poglądy wobec kulturowych ról płci kobiet i mężczyzn, wymagało analizy wielu aspektów życia codziennego obecnie i w przeszłości. Badanie „Generacje, Rodziny i Płeć Kulturowa” (GGS-PL-1) zrealizowano na reprezentatywnej próbie 20 tys. osób w okresie październik 2010 rok - luty 2011 rok. Respondentom zadano pytania dotyczące opinii na temat równości płci w sferze publicznej, w związku pomiędzy partnerami/współmałżonkami, podziału zobowiązań w rodzinie oraz na temat rodziny pochodzenia, biografii rodzinnej i zawodowej, a także organizacji zajęć w gospodarstwie domowym.

Zasady konstrukcji dwóch syntetycznych zmiennych opisujących poglądy dotyczące kulturowych ról płci są zamieszczone w poniższej tabeli. Opierała się ona na wynikach analizy czynnikowej odpowiedzi respondentów na poszczególne stwierdzenia. Ujawniła dużą zgodność poglądów dotyczących kwestii społecznych (test alfa Cronbacha $=0,743$ ) oraz poglądów na temat roli matki i ojca względem małych dzieci (test alfa Cronbacha $=0,813$ ). Pozwoliło to na utworzenie zmiennych wyrażających stopień aprobaty równości płci (egalitaryzmu) poprzez zsumowanie kodów odpowiedzi według skali Likerta. 
Tabela 1. Konstrukcja zmiennych 'gender'

Table 1. Construction of the gender variables

\section{G1 - Postawy wobec równości ptci w sferze spolecznej \\ G1 - Attitudes towards gender equality in the social sphere}

Suma kodów stopnia poparcia pięciu poniższych opinii.

- Ogólnie rzecz biorąc mężczyźni sa lepszymi przywódcami politycznymi niz kobiety.

- W sytuacji, kiedy brakuje miejsc pracy, mężczyźni powinni mieć większe prawo do pracy niż kobiety.

- Lepiej jest, aby w związu mężczyzna byt starszy od kobiety.

- Nie jest dobrze dla związku, jeśli kobieta zarabia więcej niż mężczyzna.

- Gdy rodzice sa w potrzebie, córki powinny zajmować się nimi więcej niż synowie

Respondenci wybierali dla każdej opinii jedną z odpowiedzi ze skali Likerta, którym zostały w następujący sposób przypisane kody: zdecydowanie zgadzam się $=1$; zgadzam się $=2$; ani się zgadzam ani się nie zgadzam $=3$; nie zgadzam się $=4$; zdecydowanie nie zgadzam się $=5$. Im wyższa wartość sumy, tym postawa jest bardziej egalitarna.

\section{G2 - Postawy wobec równości plci w sferze dziecka}

G2 - Attitudes towards gender equality in the child sphere

Suma kodów stopnia poparcia pięciu poniższych opinii:

- Jest ze szkoda dla matego dziecka, gdy jego matka pracuje

- Jest ze szkoda dla dzieci, gdy ich ojcowie zbytnio koncentruja się na pracy zawodowej

- Jeśli rodzice rozwioda się, lepiej jest dla dziecka, aby zostało z matka niż z ojcem

- Kobieta musi mieć dzieci, by czuć się spetniona

- Kobieta nie może zdecydować się na dziecko, jeśli nie chce pozostawać w statym zwiazku z mężczyzna

Kody były przypisane odpowiedziom w analogiczny sposób jak w przypadku opinii na temat równości płci w sferze społecznej. Im wyższa wartość kodu, tym bardziej egalitarna jest postawa wobec równości płci.

Zakres zmienności obu zmiennych jest taki sam: przyjmują wartości od 5 do 25

Najpierw przeprowadzono analizę opisową stopnia egalitaryzmu wobec równości płci w dwóch sferach, czyli analizę rozkładów zmiennych G1 i G2. Następnie dokonano analizy pogłębionej poprzez oszacowanie modeli ekonometrycznych, w których zmiennymi objaśnianymi są zmienne G1 i G2. W analizie ekonometrycznej wykorzystano uogólnione modele regresji liniowej dwóch zmiennych zależnych $\mathrm{z}$ interakcjami wielu zmiennych (generalized linear mixed model - GLM).

Trudności w formułowaniu wniosków w kategoriach przyczynowo - skutkowych w ilościowych badaniach postaw i wartości wynikają z charakteru rozpatrywanych zagadnień. Postawy są kształtowane w całym okresie życia, w dużym stopniu w dzieciństwie, jednocześnie ich zmiana następuje w przebiegu życia i to z różnych przyczyn. Dlatego w modelach ekonometrycznych istotne zmienne objaśniające pokazują tylko współwystępowanie z określonymi postawami (poglądami). Nazywane są one predyktorami (wyznacznikami). Interpretacja związków jako przyczynowo-skutkowych w takich modelach występuje bardzo rzadko. 
W celu weryfikacji hipotezy pierwszej oszacowano uogólnione modele regresji GLM dla zmiennych G1 i G2 z następującymi zmiennymi objaśniającymi: wiek, miejsce zamieszkania, wykształcenie, aktywność zawodowa stan cywilny, liczba posiadanych dzieci i częstość praktyk religijnych w ciągu roku. Aby uniknąć wzajemnego oddziaływania zmiennych, szczególnie związanych z liczbą dzieci, wprowadzono interakcje stanu cywilnego i liczby dzieci oraz miejsca zamieszkania i liczby dzieci.

Grupa modeli regresji GLM służąca weryfikacji hipotezy drugiej zawierała zmienne opisujące dom rodzinny respondenta: miejsce zamieszkania w wieku 15 lat, wykształcenie matki, pracująca matka, gdy respondent miał 15 lat, znaczenie religii $\mathrm{w}$ domu rodzinnym, liczba rodzeństwa. $\mathrm{W}$ tych modelach również wprowadzono interakcje zmiennych: pracy zawodowej i miejsca zamieszkania. Zastosowanie tej interakcji wynikało $\mathrm{z}$ bardziej tradycyjnego modelu życia na wsi w poprzednich dekadach i innego niż w mieście charakteru pracy kobiet, które - mieszkając na wsi - rozpoczynały pracę znacznie wcześniej pomagając rodzicom w gospodarstwie.

Dane wykorzystywane do szacowania modeli zostały podzielone na dwa zbiory według daty urodzenia respondentów: 1950-1969 i 1970-1989. Podział ten umożliwił analizę różnic z zbiorze istotnych predyktorów pomiędzy tymi dwiema grupami pokoleniowymi: jedna grupa całe dzieciństwo i młodość oraz znaczną część swojego dorosłego życia przeżyła przed transformacją ustrojową, zaś w drugiej grupie osób co najmniej połowa życia przypadła na lata 1990-2010.

\section{ANALIZA OPISOWA POSTAW WOBEC KULTUROWYCH RÓL PŁCI}

Ankieta panelowego badania „Generacje, Rodziny i Płeć Kulturowa” była skierowana do osób w wieku od 18 do 79 lat. Uzyskane dane potwierdziły, że bardziej egalitarne postawy wobec równości płci charakteryzowały kobiety, ale jednocześnie wśród nich występowało większe zróżnicowanie tych postaw, szczególnie w sferze obowiązków wobec dziecka (rys. 1 i 2).

Potwierdziły się też ustalenia $\mathrm{z}$ innych badań dotyczące relacji postaw względem kulturowych ról płci oraz cech demograficznych i społecznych. Płeć oraz wiek (rys. 3) wyraźnie różnicowały postawy. Kobiety w każdej grupie wieku ujawniły bardziej egalitarne postawy w sferze społecznej niż mężczyźni. Ponadto wyraźnie widać wśród kobiet i mężczyzn spadek poparcia dla równości płci wraz z przechodzeniem do starszych grup wieku. Wyjątkiem jest grupa młodych mężczyzn w wieku 20-24 i 25-29 lat, którzy w porównaniu do grupy w wieku 30-35 lat mieli średnio mniej egalitarne poglądy. Podobna sytuacja wystąpiła wśród kobiet w wieku 20-24 lata, które w odniesieniu do grupy 25-29 lat miały średnio bardziej tradycyjne poglądy. 
Rys. 1. Rozkład zmiennych G1 i G2 wśród mężczyzn

Fig. 1 Distribution of the G1 and G2 variables, males

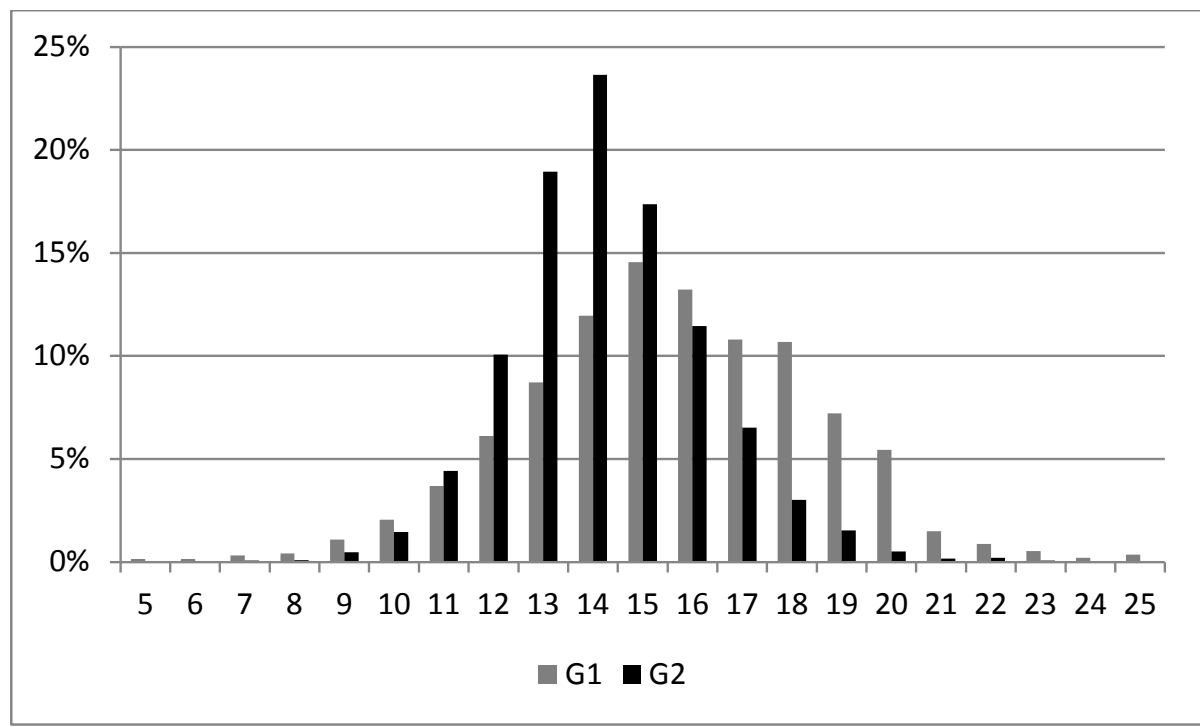

Źródło: obliczenia własne

Source: own calculations

Rys 2. Rozkład zmiennych G1 i G2 wśród kobiet

Fig. 2 Distribution of the G1 and G2 variables, females

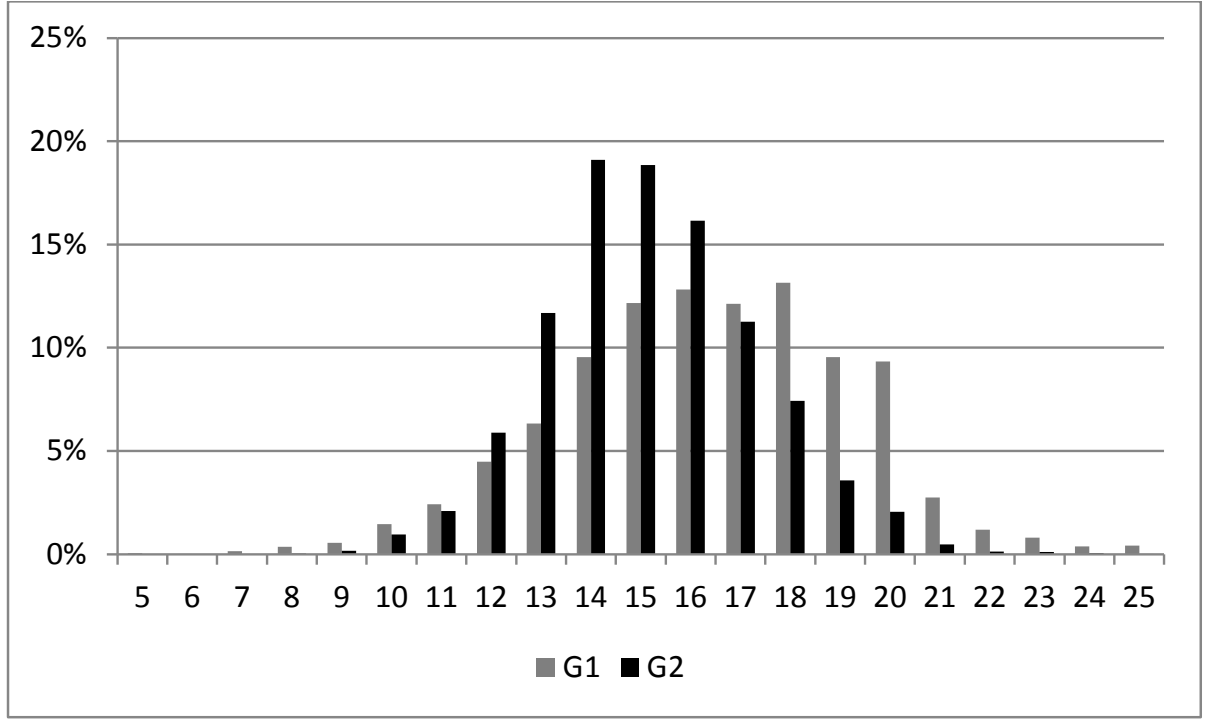

Źródło: obliczenia własne

Source: own calculations 
Najmniej egalitarne poglądy i to w każdej grupie wieku były wyrażane w odniesieniu do opinii na temat stwierdzenia, że praca zawodowa matek szkodzi małym dzieciom (składowa zmiennej G2). Opinia o szkodliwości dla dzieci zbytniego koncentrowania się ojców na pracy zawodowej nie była tak zdecydowanie podzielana przez respondentów.

Rys. 3. Średnie wartości zmiennych G1 i G2 wśród kobiet i mężczyzn według wieku Fig. 3 Mean values of the G1 and G2 variables by age, females and males

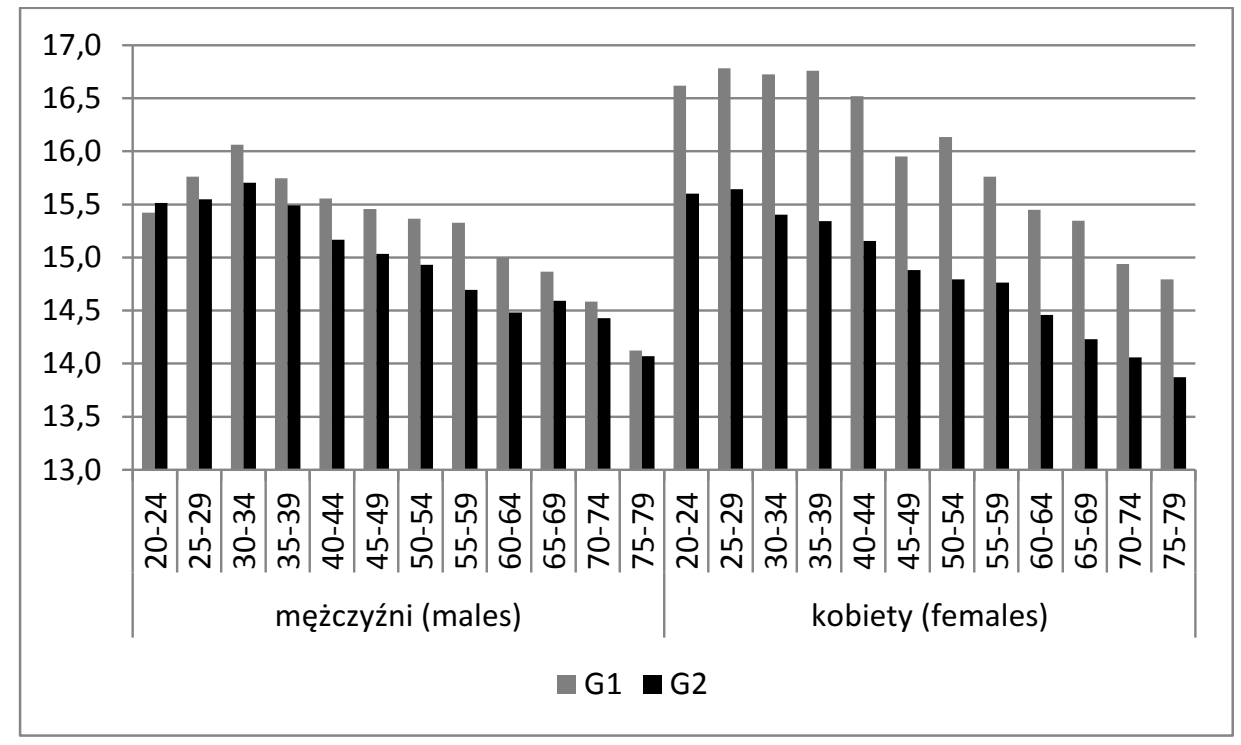

Źródło: obliczenia własne

Source: own calculations

Wykształcenie oraz aktywność zawodowa również różnicowały postawy względem kulturowych ról płci (rys. 4 i 5). Szczególnie stopień wykształcenia był wyraźnie powiązany ze stopniem egalitaryzmu poglądów na temat równości płci i to również w najstarszych grupach wieku (60-79 lat). Im wyższe wykształcenie, tym większy udział osób o bardziej egalitarnych poglądach. Dla każdego poziomu wykształcenia wyraźnie bardziej egalitarne poglądy dotyczyły sfery społecznej niż odpowiedzialności względem dziecka. Na rys. 5 przedstawiającym rozkład wartości średnich zmiennych G1 i G2 charakteryzujących postawy według statusu na rynku pracy dla osób w wieku 20-60 lat widać, że relacje pomiędzy aktywnością zawodową a poglądami nie są już tak jednoznaczne. Wprawdzie najbardziej egalitarne poglądy wyrażają pracujący, zarówno kobiety jak i mężczyźni, ale ujawnił się jeden wyjątek: bezrobotni mężczyźni w wieku 40-59 lat mieli najwyższą (nieznacznie) wartość średnią zmiennej G2 dotyczącej poglądów na temat obowiązków wobec 
dziecka. Wśród młodszych mężczyzn (20-39 lat) biernych i bezrobotnych średnie różnice wartości obu zmiennych okazały się statystycznie nieistotne. Nawet wśród starszych bezrobotnych w wieku 40-59 lat poglądy dla tych dwóch sfer średnio nie różniły się istotnie.

Rys. 4. Średnie wartości zmiennych G1 i G2 wśród kobiet i mężczyzn według wykształcenia i wieku

Fig. 4. Mean values of the G1 and G2 variables by education and age, females and males

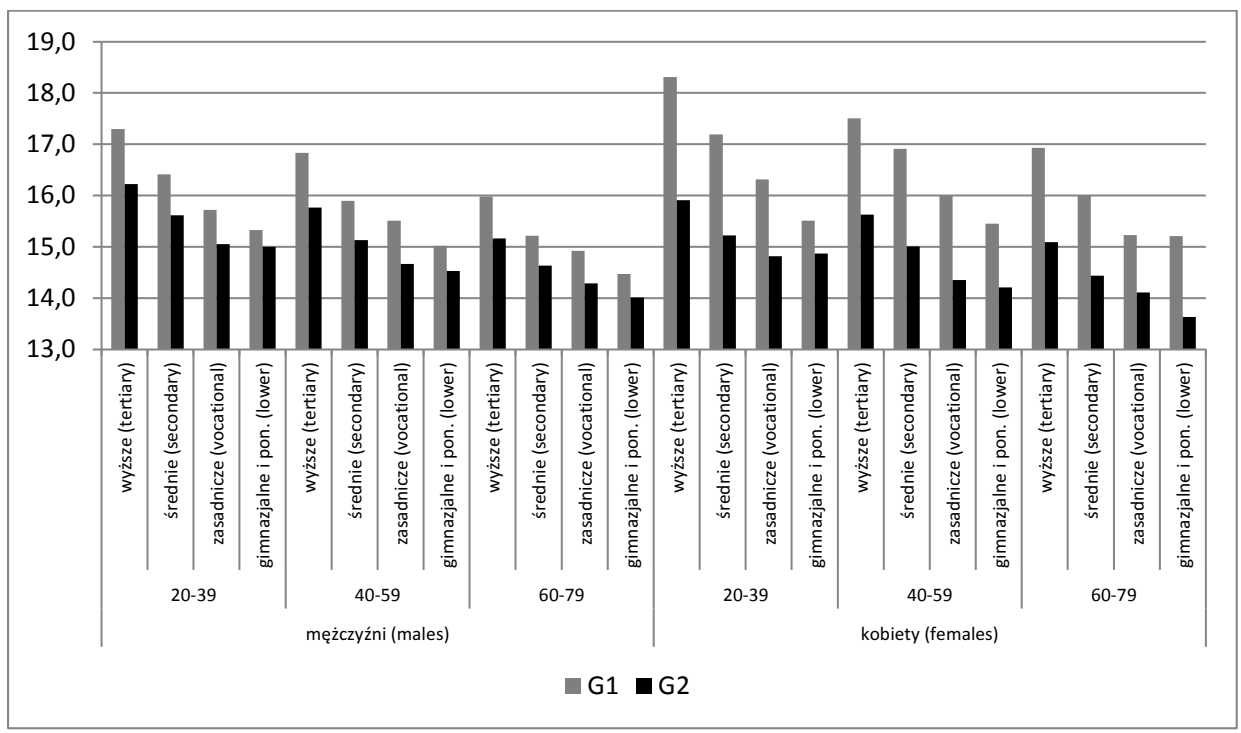

Źródło: obliczenia własne

Source: own calculations

Rozkłady zmiennych charakteryzujących postawy wobec równości płci opisują zbiorowości pod względem wybranych cech, ale nie wskazują jednoznacznie na ich istotne znaczenie jako predyktorów. Ich współwystępowanie $\mathrm{z}$ innymi cechami, jak na przykład aktywność zawodowa i wykształcenie, nie pozwala na nieobciążone wnioskowanie o istotności pojedynczej zmiennej dla kształtowania się postaw. Takie wnioskowanie umożliwia analiza ekonometryczna. 
Rys. 5. Średnie wartości zmiennych G1 i G2 wśród kobiet i mężczyzn według aktywności zawodowej i wieku

Fig. 5. Mean values of the $G 1$ and $G 2$ variables by economic activity and age, females and males

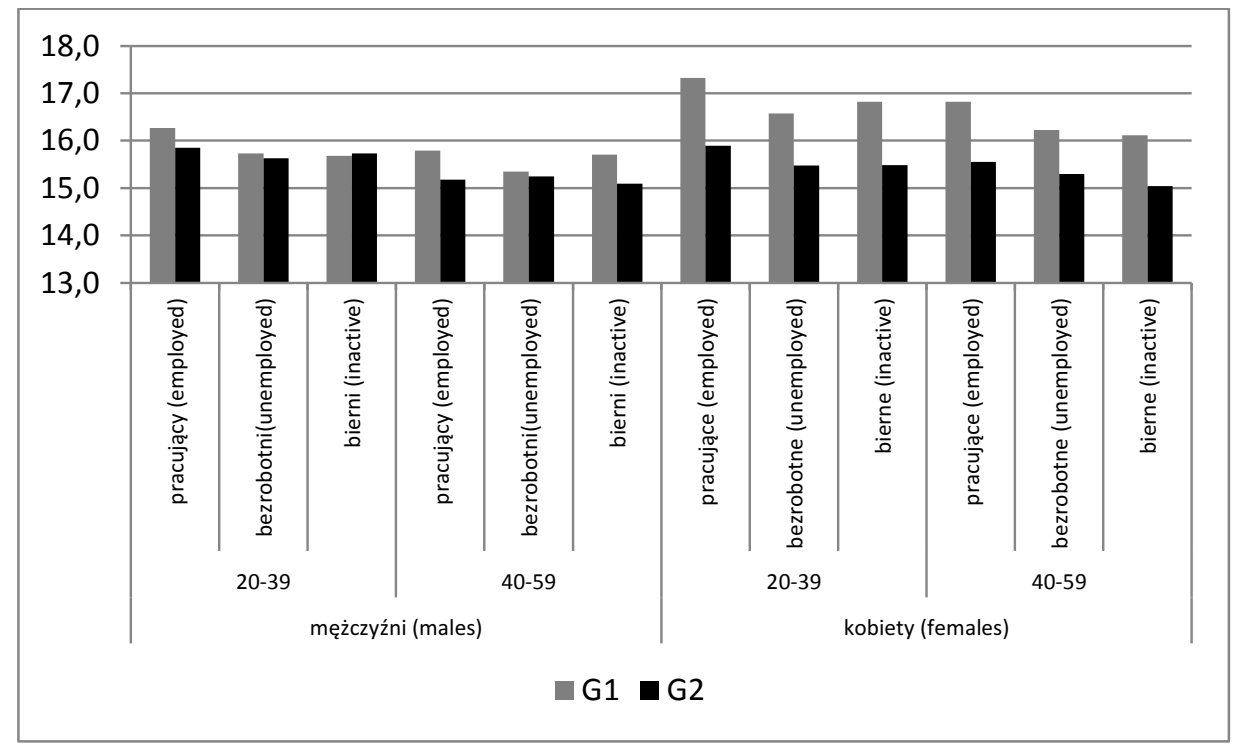

Źródło: obliczenia własne

Source: own calculations

\section{ANALIZA EKONOMETRYCZNA POSTAW WOBEC KULTUROWYCH RÓL PŁCI}

Analiza została dokonana dla zbiorowości respondentów podzielonych na dwie grupy według wieku (20-39 lat, 40-59 lat) i według płci. Na podstawie informacji z ankiety oszacowano 16 modeli dla dwóch zmiennych objaśnianych G1 i G2. Tabela 2 przedstawia oczekiwane relacje między zmiennymi G1 i G2 oraz zmiennymi uwzględnionymi w modelach. Wyniki estymacji zawierają tabele 3-6 zamieszczone w aneksie.

Oszacowania parametrów wskazały na stosunkowo niewielkie różnice w zestawach istotnych zmiennych pomiędzy kohortami oraz dość zbliżone wartości miary dopasowania modeli do danych empirycznych. We wszystkich modelach dla zmiennej G1, czyli postaw względem równości płci w sferze społecznej (Tabela 3), pojawiało się wykształcenie wyższe jako istotna zmienna o dodatnim kierunku oddziaływania, co potwierdziło znaczenie wykształcenia dla kształtowania egalitarnych poglądów na temat równości płci.

W grupie modeli dla mężczyzn dodatnia zależność wielkości miejsca zamieszkania ze zmienną G1 ujawniła się tylko wśród urodzonych w latach 1950-1969. 
Tabela 2. Oczekiwane kierunki zależności predyktorów ze zmiennymi opisującymi postawy wobec równości płci

Table 2. Expected interrelations between the gender variables and their predictors

\begin{tabular}{|c|c|c|}
\hline $\begin{array}{l}\text { Zmienna } \\
\text { Variable }\end{array}$ & $\begin{array}{l}\text { Kategoria } \\
\text { Category }\end{array}$ & $\begin{array}{c}\text { Postawy wobec równości } \\
\text { płci - zmienne G1 i G2 } \\
\text { Attitudes towards gender } \\
\text { equality - } \\
\text { the G1 and G2 variables }\end{array}$ \\
\hline \multicolumn{3}{|c|}{ Indywidualne cechy Individual characteristics } \\
\hline \multicolumn{2}{|c|}{ Wiek Age } & - \\
\hline \multirow{2}{*}{$\begin{array}{l}\text { Miejsce zamieszkania: (wieś - ref.) } \\
\text { Place of residence (rural area } \\
\text { - reference category) }\end{array}$} & $\begin{array}{l}\text { miasto pow. } 100 \text { tys., } \\
\text { town of } 100,000 \text { and over }\end{array}$ & + \\
\hline & $\begin{array}{l}\text { miasto pon. } 100 \text { tys., } \\
\text { town under } 100,000\end{array}$ & + \\
\hline \multirow{2}{*}{$\begin{array}{l}\text { Wykształcenie: } \\
\text { (pon. średniego - ref.) } \\
\text { Education (below secondary } \\
\text { - reference category) }\end{array}$} & wyższe, tertiary & + \\
\hline & średnie, secondary & + \\
\hline \multirow{2}{*}{$\begin{array}{l}\text { Aktywność zawodowa: } \\
\text { (bierny/a-ref.) } \\
\text { Economic activity (non-active } \\
\text { - reference category) }\end{array}$} & pracujący/a, employed & + \\
\hline & bezrobotny/a, unemployed & + \\
\hline \multirow{3}{*}{$\begin{array}{l}\text { Stan cywilny: } \\
\text { (rozwiedziony/a-ref.) } \\
\text { Marital status (divorced - reference } \\
\text { category) }\end{array}$} & kawaler/panna, single & + \\
\hline & żonaty/zamężna, married & - \\
\hline & $\begin{array}{l}\text { wdowiec/wdowa, } \\
\text { widow, widower }\end{array}$ & - \\
\hline \multicolumn{2}{|c|}{ Liczba dzieci Number of children } & - \\
\hline \multicolumn{2}{|c|}{ Częstość praktyk religijnych Frequency of religious practices } & - \\
\hline \multicolumn{3}{|c|}{ Cechy domu rodzinnego Characteristcs of the parental home } \\
\hline \multirow{2}{*}{$\begin{array}{l}\text { Miejsce zamieszkania w wieku } 15 \text { lat: } \\
\text { (wieś - ref.) } \\
\text { Place of residence (rural area } \\
\text { - reference category) }\end{array}$} & $\begin{array}{l}\text { miasto pow. } 100 \text { tys., } \\
\text { town of } 100,000 \text { and over }\end{array}$ & + \\
\hline & $\begin{array}{l}\text { miasto pon. } 100 \text { tys., } \\
\text { town under } 100,000\end{array}$ & + \\
\hline \multirow{2}{*}{$\begin{array}{l}\text { Wykształcenie matki: (poniżej } \\
\text { średniego - ref.) } \\
\text { Mother's education (below secondary } \\
\text { - reference category) }\end{array}$} & wyższe, tertiary & + \\
\hline & średnie, secondary & + \\
\hline $\begin{array}{l}\text { Pracująca matka (nie-ref.) } \\
\text { Mother at paid work (non-working } \\
\text { - reference category) }\end{array}$ & tak, yes & + \\
\hline \multicolumn{2}{|c|}{ Liczba rodzeństwa Number of siblings } & - \\
\hline \multirow{2}{*}{$\begin{array}{l}\text { Znaczenie religii w domu rodzinnym: } \\
\text { (nieważne - ref.) Value of religion } \\
\text { at the parental home (unimportant- } \\
\text { reference category) }\end{array}$} & ważne, important & - \\
\hline & $\begin{array}{l}\text { ani ważne, ani nieważne, } \\
\text { neither important nor } \\
\text { unimportant }\end{array}$ & - \\
\hline
\end{tabular}


Natomiast w młodszej grupie mężczyzn tylko duże miasta wpływały dodatnio na zmienną G1 w porównaniu do wsi. Odmienna sytuacja wystąpiła wśród kobiet. W młodszej grupie ujawnił się dodatni związek obu kategorii miast, a w starszej grupie respondentek żadna kategoria miejsca zamieszkania nie była istotna. Istotność zmiennej stan cywilny ujawniła się tylko w starszych kohortach. Owdowiali mężczyźni wyrażali bardziej egalitarne poglądy w porównaniu do rozwiedzionych, zaś rozwiedzione kobiety - w porównaniu do kobiet zamężnych. Ta zależność nie wystąpiła w młodszych kohortach nawet w połączeniu z liczbą dzieci.

Praca zawodowa jako dodatni predyktor egalitarnych poglądów ujawniła się tylko w modelach dla zmiennej G1 oszacowanych dla kobiet. W tych samych modelach można było również dostrzec niejednoznaczność kierunku zależności zmiennej wiek. Jedynie wśród kobiet urodzonych w latach 1950-1969 kierunek współzależności był ujemny, czyli im starsze kobiety tym mniej aprobaty dla równości płci. W modelach dla młodszych grup wieku kierunek był odwrotny zarówno wśród mężczyzn jak i kobiet. Taki wynik potwierdza zależności widoczne w analizie opisowej: najmłodsze roczniki w porównaniu do trzydziestolatków miały średnio bardziej tradycyjne poglądy.

W każdym modelu dla zmiennej G1 wśród kobiet i mężczyzn (Tabela 3) religijność $\mathrm{w}$ stosunkowo niedużym stopniu była ujemnie związana $\mathrm{z}$ tą zmienną. Natomiast liczba dzieci okazała się istotna tylko w połączeniu $\mathrm{z}$ innymi zmiennymi (mężczyźni: stan cywilny i miejsce zamieszkania (1950-1969), wśród kobiet tylko z miejscem zamieszkania (1950-1969). Istotnie słabszy stopień egalitaryzmu poglądów wykazywali mężczyźni urodzeni w latach 1950-1969 wśród wdowców $z$ dziećmi i mieszkających $w$ miastach $z$ dziećmi. W młodszej grupie pokoleniowej zróżnicowanie według liczby dzieci w powiązaniu z tymi zmiennych już się nie ujawniło.

We wszystkich modelach dotyczących zmiennej G2 (Tabela 4), tak jak wcześniej, istotne były: miejsce zamieszkania, wykształcenie i religijność. Zmienna stan cywilny tylko w niewielkim stopniu różnicowała zbiorowość kobiet urodzonych w latach 1950-1969. Wśród nich bardziej egalitarne poglądy w porównaniu do kobiet rozwiedzionych wykazywały panny. Wiek podobnie jak w poprzednich modelach był ujemnie skorelowany wśród kobiet i mężczyzn urodzonych latach 1950-1969 i dodatnio wśród kobiet urodzonych w latach 1970-1989. W tej grupie modeli można było oczekiwać większego znaczenia liczby dzieci. Jednak tylko w modelu dla kobiet urodzonych w latach 1950-1969 zmienna ta ujawniła się samodzielnie jako istotna ujemnie. W interakcji z klasą miejscowości pojawiła się również w starszym pokoleniu kobiet i mężczyzn. Ten ostatni wynik wskazuje, że mniej egalitarne poglądy wyrażali starsi mężczyźni $z$ dziećmi w miastach poniżej 100 tys. niż na wsi, a bardziej egalitarne - starsze kobiety mieszkające $z$ dziećmi $w$ dużych $i$ w miejszych miastach niż na wsi. W młodszym pokoleniu istotność tych interakcji już się nie ujawniła.

Druga grupa modeli dotyczyła zależności pomiędzy zmiennymi charakteryzującymi poglądy w dwóch rozważanych sferach a zmiennymi opisującymi dom 
rodzinny (Tabela 5 i Tabela 6). Zmienną kontrolną był wiek. Modele te w mniejszym stopniu wyjaśniają zmienność zmiennych G1 i G2, ale podobnie jak w poprzednich modelach wyksztatcenie (tym razem matki), miejsce zamieszkania (tym razem w młodości) i religijność (tym razem w domu rodzinnym) ujawniły istotny związek z poglądami respondentów, tzn. im wyższe wykształcenie matki, im większa miejscowość zamieszkania (przede wszystkim w starszym pokoleniu w modelach zmiennej G2) i mniejsze znaczenie religii w domu rodzinnym, tym bardziej egalitarne poglądy wyrażali respondenci.

Ponadto prawie we wszystkich modelach istotną zmienną okazała się liczba rodzeństwa. Znak stojący przy zmiennej pokazał, że im mniej rodzeństwa, tym bardziej nowoczesne poglądy respondentów. Wyjątkiem były kobiety urodzone w latach 1970-1989, dla których zależność ta się nie ujawniła.

Zmienna charakteryzująca aktywność zawodowa matek w okresie młodości mężczyzn była istotnie powiązana tylko ze stopniem egalitaryzmu respondentów urodzonych w latach 1950-1969 w modelu dotyczącym zmiennej G1. Kierunek współwystępowania wskazał, że synowie pracujących matek w przeszłości, czyli w latach od 1965-1985, w chwili badania mieli średnio mniej nowoczesne poglądy niż ich rówieśnicy - synowie matek niepracujących. Ten kierunek zależności ujawnił się po wprowadzeniu interakcji tej zmiennej z klasą miejscowości. Połączenie to pokazało, że respondenci pochodzący z rodzin, w których matki pracowaly i mieszkajacy w miastach mieli średnio bardziej nowoczesne poglądy w porównaniu do synów matek niepracujacych i mieszkających na wsi. Taki sam kierunek zależności pojawił się również wśród kobiet urodzonych w latach 1970-1989 w modelach dla zmiennej G1: kobiety, których matki pracowaty i mieszkaty w mniejszych miastach miały średnio bardziej egalitarne poglądy niż kobiety, których matki nie pracowaty na wsi. W modelach zmiennej G2 dla kobiet aktywność zawodowa ich matek z połączeniu z miejscem zamieszkania okazała się istotna w każdej z dwóch wyróżnionych generacji: córki matek pracujacych i mieszkajacych $w$ mniejszych miastach miały średnio bardziej nowoczesne poglądy niż córki matek niepracujacych i mieszkajacych na wsi.

\section{PODSUMOWANIE}

Analiza poglądów na temat równości płci w sferze społecznej oraz w sferze odpowiedzialności za dziecko potwierdziła, że w Polsce poglądy te są stosunkowo tradycyjne. Niewiele osób opowiadało się w pełni za równością $\mathrm{w}$ poruszanych w analizach aspektach. Najbardziej tradycyjne poglądy dotyczyły sfery odpowiedzialności za dziecko.

Na podstawie danych z przełomu lat 2010 i 2011 opisane zostały postawy wobec kulturowych ról płci dwóch grup pokoleniowych kobiet i mężczyzn i ich zróżnicowanie według cech demograficznych i społecznych. Wspólnymi cechami osób 
o bardziej egalitarnych poglądach niezależnie od pokolenia były: wykształcenie wyższe, zamieszkiwanie $\mathrm{w}$ dużym mieście i mniejsza częstotliwość uczestnictwa w praktykach religijnych. Nie potwierdziły się natomiast przypuszczenia dotyczące współzależności poglądów na temat równości płci z liczbą dzieci oraz aktywnością zawodową. Zmienne te były istotne tylko wśród kobiet: wystąpiła ujemna zależność liczby dzieci w modelu poglądów starszych kobiet na temat równości płci w sferze dziecka, a aktywność zawodowa miała znaczenie tylko dla poglądów w sferze społecznej zarówno wśród kobiet młodszych jak i starszych - praca zawodowa sprzyja poglądom bardziej egalitarnym.

Generalnie, uzyskane wyniki potwierdzają pierwszą hipotezę głoszącą, że istotnymi predyktorami poglądów kobiet i mężczyzn dotyczących równości płci w sferze społecznej i sferze odpowiedzialności za dziecko są: wykształcenie, aktywność zawodowa, miejsce zamieszkania, liczba dzieci oraz częstość praktyk religijnych, aczkolwiek ich znaczenie jest odmienne dla poszczególnych grup pokoleniowych oraz dla kobiet i mężczyzn, tzn. nie wszystkie zmienne były istotne statystycznie w rozpatrywanych modelach. Innymi słowy, zestawy predykatorów różniły się między kobietami i mężczyznami, a także między grupami pokoleniowymi zwłaszcza dla kobiet.

Oszacowania modeli zawierających zmienne charakteryzujące dom rodzinny respondentów potwierdziły hipotezę drugą o znaczeniu domu rodzinnego dla kształtowania się poglądów dotyczących równości płci w obu rozpatrywanych sferach. Prawie wszystkie wybrane zmienne do modeli okazały się statystycznie istotne, zarówno w modelach poglądów w sferze społecznej jak i w sferze odpowiedzialności za dziecko. Wyjątkiem była aktywność zawodowa matek, która tylko dla starszych mężczyzn w modelach poglądów na temat równości płci w sferze społecznej ujawniła negatywne znaczenie pracującej matki. Wykształcenie matki było istotnie dodatnio związane ze zmiennymi G1 i G2 w każdym modelu kobiet i mężczyzn. Jest to najbardziej znaczący predyktor postaw wobec równości płci. Wyniki potwierdziły związek cech domu rodzinnego z poglądami w dorosłym życiu i jednocześnie ujawniły „dziedziczność” ich znaczenia - kierunek i istotność zależności tych samych cech respondentów, tak kobiet jak i mężczyzn, był taki sam jak dla ich matek i domu rodzinnego.

Analizowanie poglądów w dwóch grupach generacyjnych pozwoliło ujawnić kilka różnic, przede wszystkim wśród kobiet. Dotyczyły one współzależności poglądów z wiekiem, miejscem zamieszkania i stanem cywilnym. W młodszej grupie pokoleniowej kobiet większego znaczenia dla egalitarnych poglądów w sferze społecznej nabrało zamieszkiwanie w mieście, w starszym pokoleniu kobiet utrzymywało się więcej tradycyjnych poglądów wśród mężatek. W sferze poglądów na temat dziecka tylko wśród starszych kobiet ujawniła się ujemna zależność nowoczesnych poglądów z liczbą dzieci.

Wśród mężczyzn podział na generacje nie pokazał wielu różnic w zestawie predyktorów postaw wobec równości płci. Na uwagę zasługuje praca zawodowa matki, która tylko w starszym pokoleniu okazała się ujemnie oddziaływać na poglądy męż- 
czyzn dotyczących sfery społecznej. Różnice pojawiły się również przy zmiennej wiek, która była dodatnio skorelowana z poglądami w młodszej grupie pokoleniowej i ujemnie w starszej. Powyższa relacja wśród osób urodzonych w latach 1970-1989 może wynikać z tego, że wśród dwudziestolatków była jeszcze znaczna grupa, która nie doświadczyła trudności godzenia życia zawodowego i rodzinnego, a ich poglądy wyniesione $\mathrm{z}$ domu rodzinnego nie zostały skonfrontowane $\mathrm{z}$ sytuacją osób łączących wychowanie dzieci i pracę zawodową.

Powyższe wyniki tylko częściowo potwierdziły rezultaty uzyskane $\mathrm{w}$ analizie empirycznej Philipova (2008), który korzystał z danych pochodzących z badania Population Policy Acceptance Survey zrealizowanego w Polsce w końcu 2001 roku. Jego wyniki wskazywały, że wśród mężczyzn występowała istotna korelacja pomiędzy postawami i wykształceniem oraz aktywnością zawodową, a wśród kobiet pomiędzy stanem cywilnym, wiekiem i znaczeniem religii w ich życiu. W naszej analizie wykształcenie wyższe i znaczenie religii są predyktorem egalitarnych poglądów kobiet i mężczyzn, a praca zawodowa - ważnym wyznacznikiem aprobaty równości płci $\mathrm{w}$ sferze społecznej jedynie wśród kobiet. Zmiana znaczenia stanu cywilnego może wynikać z rosnącego zróżnicowania sytuacji rodzinnej respondentów i malejącej wartości informacyjnej tej zmiennej jako charakteryzującej tę sytuację. Natomiast odmienna od oczekiwanej zależność poglądów od wieku wśród młodszego pokolenia ujawniła się w wyniku oddzielnego analizowania dwóch grup pokoleniowych.

Różnice między wynikami niniejszych analiz i tymi, jakie uzyskał D.Philipov mogą wynikać $\mathrm{z}$ innej konstrukcji zmiennych charakteryzujących postawy wobec kulturowych ról płci. Wśród zmiennych D.Philipova tylko stwierdzenie „Dziecko w wieku przedszkolnym prawdopodobnie cierpi, jeśli jego matka pracuje" pojawiło się w badaniu GGS-PL-1 w nieznacznie zmienionej formie Jest ze szkoda dla matego dziecka, gdy jego matka pracuje. Pozostałe stwierdzenia tworzące zmienne opisujące postawy były albo inne albo tylko częściowo pokrywały się z tymi, z których korzystano w tym artykule. Dotyczyły one przede wszystkim spełnienia się kobiety w roli żony i matki, podziału obowiązków w rodzinie, skutków braku czasu dla rodziny wśród pracujących rodziców i pracy zawodowej kobiet.

Innym czynnikiem mogącym wpłynąć ma różnice wyników był upływ czasu. Badanie GGS-PL-1 było zrealizowane prawie dekadę później. W tym okresie miał miejsce kryzys gospodarczy, zmieniał się rynek pracy, a także uległa zmianom tematyka debaty publiczne na temat rodziny i podziału obowiązków, o czym już wspominano. Pod koniec tego okresu urodziło się w Polsce więcej dzieci, w tym wiele planowanych już wcześniej. Te opóźnione decyzje o urodzeniu dzieci były realizowane w dużym stopniu wśród pracujących trzydziestolatków, którzy stawali przed problemem godzenia obowiązków domowych i zawodowych. To również mogło wpłynąć na wyrażane poglądy na temat równości płci.

Kolejna druga runda panelowego badania „Generacje, Rodziny i Płeć Kulturowa”, realizowana w czwartym kwartale 2014 roku, pozwoli na pozyskanie danych 
nie tylko o zmianach w czasie samych postaw respondentów wobec kulturowych ról płci. Umożliwi także określenie, czy były one powiązane ze zdarzeniami, jakie wystąpiły w życiu respondentów w tym czasie (np. urodzenie dziecka, podjęcie czy utrata pracy, zmiana partnera, zmiana miejsca pobytu).

\section{LITERATURA}

Aronson E., 1997, Człowiek istota społeczna, Warszawa: PWN.

Blossfeld, H-P, Drobnič, S., (red.) 2001, Careers of Couples in Contemporary Societies: From Male Breadwinner to Dual-Earner Families. Oxford: Oxford University Press.

Caldwell, J.C.,1976, Towards a restatement of demographic transition theory, "Population and Development Review", nr 2, 321-366.

Engelhardt H., Kogel T., Prskawetz A., 2004, Fertility and women's employment reconsidered: A macrolevel time-series analysis for developed countries, 1960-2000, "Population Studies", nr 58, 1, $109-120$.

Eysenck H., Eysenck M., 1998, Podpatrywanie umystu, Gdańsk: GWP.

Fischer C.S., Hout M., 2006, Century of Difference: How America Changed in the Last One Hundred Years. New York: Russell Sage Foundation.

Frejka T., 2008, Determinants of family formation and childbearing during the societal transition in central and Eastern Europe, [w:] T. Frejka, T. Sobotka, J.M. Hoem, L. Toulemon (red.) Childbearing Trends and Policies in Europe, "Demographic Research", nr 19; Article 22: 139-170.

Goldin C., 2006, The quiet revolution that transformed women's employment, education, and family, "American Economic Review", nr 96, 2, 1-21.

Goldscheider F., Oláh L., Puur A., 2010, Reconciling studies of men's gender attitudes and fertility; Response to Westoff and Higgins, "Demographic Research", nr 22, 8, 189-198. http://www. demographic-research.org/Volumes/Vol22/8/

Inglehart, R., 1989, Culture shift in advanced industrial society. Princeton, NJ: Princeton University Press.

Inglehart, R., Norris, P.,2003, Rising tide: Gender equality and cultural change. New York: Cambridge University Press.

Inglehart, R.; Norris, P., 2009, Wzbierająca fala: równouprawnienie płci a zmiana kulturowa na świecie. Przełożyła B. Hellmann. Warszawa: PIW.

Jackson, R.M., 1998, Destined for equality: The inevitable rise of women's status. Cambridge: Harvard University Press.

Kaa D.J. van de, Lesthaeghe R.,1986, Twee demografische transities, [w:] D.J. van de Kaa, R. Lesthaeghe. (red.) Bevõlking: groei en krimp, Deventer: van Loghem Slaterus.

Kohler H-P., Billari F. C., Ortega J. A., 2006, Low Fertility in Europe: Causes, Implications and Policy Options, [w:] F. R. Harris (red.) The Baby Bust: Who will do the Work? Who Will Pay the Taxes? (s. 48-109), Lanham, MD: Rowman \& Littlefield Publishers.

Kotowska I.E., 1999, Drugie przejście demograficzne i jego uwarunkowania, [w:] I.E. Kotowska (red.), Przemiany demograficzne $w$ Polsce $w$ latach 90. w świetle drugiego przejścia demograficznego, Warszawa: Oficyna Wydawnicza SGH.

Kotowska I.E., 2005, Work and parenthood: main findings of comparative data analysis and some policy implications, "Studia Demograficzne", nr 2/148, 54-82.

Kotowska I.E., Jóźwiak J., Matysiak A., Baranowska A., 2008, Poland: Fertility decline - a response to profound societal change and transformations in the labour market? "Demographic Research', Special Collection 7: Childbearing Trends and Policies in Europe, nr 19, article 22, 795-854. http:// www.demographic-research.org/ 
Kotowska I.E., 2009, Zmiany modelu rodziny a zmiany aktywności zawodowej kobiet $w$ Europie, [w:] I.E. Kotowska (red.), Strukturalne i kulturowe uwarunkowania aktywności zawodowej kobiet $w$ Polsce, Wydawnictwo Naukowe SCHOLAR.

Kotowska I.E., Jóźwiak J., 2011, Panelowe badanie przemian relacji między pokoleniami, w rodzinie oraz między kobietami i mężczyznami: Generacje, Rodziny i Płeć Kulturowa GGS-PL, „Studia Demograficzne", nr 1/159, 99-106.

Lesthaeghe R., Surkyn J., 1988, Cultural Dynamics and Economic Theories of Fertility Change, "Population and Development Review", nr 1.

Lestaheghe R., Surkyn J., 2002, New forms of household formation in Central and Eastern Europe: are they related to newly emerging value orientations, "Economic Survey of Europe" 2002/1. New York and Geneva: United Nations, Economic Commission for Europe, 197-216.

Liefbroer A.C., Corijn M., 1999, Who, What, Where, and When? Specifying the Impact of Educational Attainment and Labour Force Participation on Family Formation, "European Journal of Population", nr 15, 1, 45-75.

Mądrzycki T.,1997, Psychologiczne prawidlowości ksztaltowania się postaw, Warszawa: WSiP.

Mason, K.O., 1995, Gender and Demographic Change: What do we Know? IUSSP Paper.

Matysiak A., 2006, Sharing Professional and household duties within the Polish couples - preferences and actual choices, "Studia Demograficzne", nr 1/147, 122-153.

Matysiak A., 2011, Interdependencies between Fertility and Women's Labour Supply, "European Studies of Population", nr 17, Dortrecht, Heidelberg, London, New York: Springer.

Matysiak A., 2012, Fertility developments in Central and Eastern Europe: the role of work-family tensions, "Demográfia" - The English Edition, 54(5), 307-325.

McDonald P., 2000a, Gender equity in theories of fertility, "Population and Development Review", nr 26, 3, 427-439.

McDonald P. ,2000b, Gender equity, social institutions and the future of fertility, "Journal of Population Research", nr. 17, 1, 1-12.

Muszyńska M., 2007, Structural and cultural determinants of fertility in Europe, Warsaw: Warsaw School of Economics Publisher.

Mynarska M., Styrc M., 2014, Preferencje i ograniczenia. Czynniki determinujące intencje posiadania pierwszego i drugiego dziecka [w:] A. Matysiak (red.), Nowe wzorce formowania i rozwoju rodziny w Polsce. Przyczyny oraz wpływ na zadowolenie z życia, Scholar, Warszawa.

Neyer G., Lappergard T., Vignoli D., 2011, Gender equality and fertility: Which equality matters, "European Journal of Population", nr 29, 3, 245-272.

Oláh L.Sz., Bernhardt E.M, 2008, Sweden: Combining childbearing and gender equality, "Demographic Research", Special Collection 7: Childbearing Trends and Policies in Europe, nr 19, article 28, 1105-1144. http://www.demographic-research.org/

Philipov D., 2008, The three dimensions of gender-role attitudes, [w:] Ch. Höhn, D. Avramov, I. Kotowska (red.), People, Population Change and Policies: Lessons from the Population Policy Acceptance Study (s. 153-174), Vol 2. Springer.

Prskawetz A., Mamolo M., Engelhardt H., 2010, On the relation between fertility, natality, and nuptiality, "European Sociological Review", nr 26, 6, 675-689.

Rindfuss, R.R., BrewsterK.L., Kavee A.L.,1996, Women, work, and children: Behavioral and attitudinal change in the United States, "Population and Development Review", 22:457-482.

Rindfuss R.R., Guzzo K.B., Morgan S.P., 2003, The Changing Institutional Context of Low Fertility, "Population Research and Policy Review", nr 22, 411-438.

Sobotka T., 2004, Postponement of Childbearing and Low Fertility in Europe. Amsterdam: Dutch University Press.

Thornton A., Young-DeMarco L.,2001, Four Decades of Trends in Attitudes Toward Family Issues in the United States: The 1960s Through the 1990s, "Journal of Marriage and the Family", nr 63, 4. 


\section{ANEKS}

Tabela 3. Wyniki estymacji modeli GLM zmiennej G1 (postawy wobec równości płci w sferze społecznej) dla mężczyzn i kobiet, kohorty urodzeniowe 1950-1969 i 1970-1989

Table 3. Estimation results of the G1-GLM models (attitudes towards gender equality in the social sphere) for males and females, birth cohorts of 1950-1969 and 1970-1989

\begin{tabular}{|c|c|c|c|c|c|}
\hline \multirow{2}{*}{$\begin{array}{l}\text { Zmienna } \\
\text { Variable }\end{array}$} & \multirow{2}{*}{$\begin{array}{l}\text { Kategoria } \\
\text { Category }\end{array}$} & \multicolumn{2}{|c|}{ Mężczyźni Males } & \multicolumn{2}{|c|}{ Kobiety Females } \\
\hline & & $1950-1969$ & $1970-1989$ & $1950-1969$ & $1970-1989$ \\
\hline \multicolumn{2}{|l|}{ Wiek, Age } & $-0,011$ & $0,021 * *$ & $-0,020 * *$ & $0,030 * * *$ \\
\hline \multirow{2}{*}{$\begin{array}{l}\text { Miejsce zamieszkania } \\
\text { (wieś - ref.), } \\
\text { Place of residence } \\
\text { (rural area - reference } \\
\text { category) }\end{array}$} & $\begin{array}{l}\text { miasto pow. } 100 \text { tys., } \\
\text { town of } 100,000 \text { and } \\
\text { over }\end{array}$ & $1,025^{* * *}$ & $0,869 * *$ & 0,059 & $1,019 * * *$ \\
\hline & $\begin{array}{l}\text { miasto pon. } 100 \text { tys., } \\
\text { town under } 100,000\end{array}$ & $0,782 * *$ & 0,293 & 0,344 & $0,674 * * *$ \\
\hline \multirow{2}{*}{$\begin{array}{l}\text { Wykształcenie (poniżej } \\
\text { średniego - ref.), } \\
\text { Education (below } \\
\text { secondary reference } \\
\text { category) }\end{array}$} & wyższe, tertiary & $1,019 * * *$ & $1,119 * * *$ & $1,322 * * *$ & $1,510^{* * *}$ \\
\hline & średnie, secondary & $0,332 * *$ & $0,612 * * *$ & $0,859 * * *$ & $0,836 * * *$ \\
\hline \multirow{2}{*}{$\begin{array}{l}\text { Aktywność zawodowa } \\
\text { (bierny-ref.), } \\
\text { Economic activity } \\
\text { (non-active - reference } \\
\text { category) }\end{array}$} & $\begin{array}{l}\text { pracujący/a, } \\
\text { employed }\end{array}$ & 0,101 & 0,208 & $0,394 * * *$ & $0,255^{* *}$ \\
\hline & $\begin{array}{l}\text { bezrobotny/a, } \\
\text { unemployed }\end{array}$ & $-0,216$ & 0,085 & 0,201 & 0,119 \\
\hline \multirow{3}{*}{$\begin{array}{l}\text { Stan cywilny } \\
\text { (rozwiedziony/a-ref.), } \\
\text { Marital status (divorced } \\
\text { - reference category) }\end{array}$} & $\begin{array}{l}\text { kawaler/panna, } \\
\text { single }\end{array}$ & $-0,074$ & 0,149 & $-0,188$ & $-0,203$ \\
\hline & $\begin{array}{l}\text { żonaty/zamężna, } \\
\text { married }\end{array}$ & 0,352 & 0,629 & $-0,751 * *$ & $-0,223$ \\
\hline & $\begin{array}{l}\text { wdowiec/wdowa, } \\
\text { widowed }\end{array}$ & $1,752 * * *$ & $-1,224$ & $-0,483$ & 1,090 \\
\hline \multicolumn{2}{|c|}{ Liczba dzieci Number of children } & 0,175 & 0,223 & $-0,186$ & 0,251 \\
\hline \multicolumn{2}{|c|}{$\begin{array}{l}\text { Częstość praktyk religijnych } \\
\text { Frequency of religious practices }\end{array}$} & $-0,008 * * *$ & $-0,005 * * *$ & $-0,005^{* * *}$ & $-0,006 * * *$ \\
\hline \multirow{3}{*}{$\begin{array}{l}\frac{\text { Stan cywilny*liczba }}{\text { dzieci }} \\
\text { (rozwiedziony/a*liczba } \\
\text { dzieci }- \text { ref.) } \\
\text { Marital status } * \text { number } \\
\frac{\text { of children }}{\text { (divorced }{ }^{*} \text { number of }} \\
\text { children - reference } \\
\text { category }\end{array}$} & $\begin{array}{l}\text { kawaler/panna* } \\
\text { liczba dzieci, single } \\
\text { *number of children }\end{array}$ & 0,480 & $-0,483$ & 0,262 & $-0,255$ \\
\hline & $\begin{array}{l}\text { żonaty/zamężna* } \\
\text { liczba dzieci, } \\
\text { married * number of } \\
\text { children }\end{array}$ & $-0,135$ & $-0,332$ & 0,130 & $-0,229$ \\
\hline & $\begin{array}{l}\text { wdowiec/wdowa* } \\
\text { liczba dzieci, } \\
\text { widowed *number of } \\
\text { children }\end{array}$ & & & $-0,043$ & $-0,614$ \\
\hline
\end{tabular}


Spoleczno-ekonomiczne predyktory pogladów kobiet i mężczyzn...

Tabela 3.

\begin{tabular}{|c|c|c|c|c|c|}
\hline \multirow{2}{*}{$\begin{array}{l}\text { Zmienna } \\
\text { Variable }\end{array}$} & \multirow{2}{*}{$\begin{array}{l}\text { Kategoria } \\
\text { Category }\end{array}$} & \multicolumn{2}{|c|}{ Mężczyźni Males } & \multicolumn{2}{|c|}{ Kobiety Females } \\
\hline & & 1950-1969 & $1970-1989$ & 1950-1969 & 1970-1989 \\
\hline \multirow{2}{*}{$\begin{array}{l}\text { Miejsce zamieszkania * } \\
\text { liczba dzieci } \\
\text { (wieś*liczba dzieci } \\
\text { - ref.) } \\
\text { Place of } \\
\text { residence }{ }^{*} \text { number } \\
\text { of children (rural } \\
\text { area*number of children } \\
\text { - reference category) }\end{array}$} & $\begin{array}{l}\text { miasto pow. } 100 \text { tys } \\
* \text { liczba dzieci, town } \\
\text { of } 100,000 \text { and over } \\
* \text { number of children }\end{array}$ & $-0,242$ & $-0,077$ & $0,255^{* *}$ & $-0,329 * * *$ \\
\hline & $\begin{array}{l}\text { miasto pon. } 100 \text { tys } \\
* \text { liczba dzieci, town } \\
\text { under } 100,000 * \\
\text { number of children }\end{array}$ & $-0,192$ & 0,168 & 0,076 & $-0,096$ \\
\hline \multicolumn{2}{|l|}{$\mathrm{N}$} & 3081 & 2928 & 4059 & 3476 \\
\hline \multicolumn{2}{|c|}{$\mathrm{R}^{2}$} & 0,051 & 0,060 & 0,080 & 0,086 \\
\hline
\end{tabular}

Źródło: Obliczenia własne na podstawie danych z GGS-PL-1. Krytyczny poziom istotności: $* * *<0,01 ; * *<0,05 ; *<0,1$

Source: Own calculations based on GGS-PL-1 data. Significance level: ***<0,01; **<0,05; $*<0,1$

Tabela 4. Wyniki estymacji modeli GLM zmiennej G2 (postawy wobec równości płci w sferze odpowiedzialności za dziecko) dla mężczyzn i kobiet, kohorty urodzeniowe 1950-1969 i $1970-1989$

Table 4. Estimation results of the G2-GLM models (attitudes towards gender equality regarding the responsibility for a child) for males and females, birth cohorts of 1950-1969 and 1970-1989

\begin{tabular}{|c|c|c|c|c|c|}
\hline \multirow{2}{*}{$\begin{array}{l}\text { Zmienna } \\
\text { Variable }\end{array}$} & \multirow{2}{*}{$\begin{array}{l}\text { Kategoria } \\
\text { Category }\end{array}$} & \multicolumn{2}{|c|}{ Mężczyźni Males } & \multicolumn{2}{|c|}{ Kobiety Females } \\
\hline & & 1950-1969 & 1970-1989 & 1950-1969 & 1970-1989 \\
\hline \multicolumn{2}{|l|}{ Wiek, Age } & $-0,029 * * *$ & 0,008 & $-0,012^{*}$ & $0,028 * * *$ \\
\hline \multirow{2}{*}{$\begin{array}{l}\text { Miejsce zamieszkania } \\
\text { (wieś - ref.), } \\
\text { Place of residence } \\
\text { (rural area - reference } \\
\text { category) }\end{array}$} & $\begin{array}{l}\text { miasto pow. } 100 \text { tys., } \\
\text { town of } 100,000 \text { and } \\
\text { over }\end{array}$ & $0,358^{* *}$ & $0,535 * * *$ & $0,344 * *$ & $0,736^{* * *}$ \\
\hline & $\begin{array}{l}\text { miasto pon. } 100 \text { tys., } \\
\text { town under } 100,000\end{array}$ & $0,489 * * *$ & $0,223^{*}$ & 0,057 & 0,278 \\
\hline \multirow{2}{*}{$\begin{array}{l}\text { Wykształcenie (poniżej } \\
\text { średniego - ref.), } \\
\text { Education (below } \\
\text { secondary reference } \\
\text { category) }\end{array}$} & wyższe, tertiary & $0,703 * * *$ & $0,899 * * *$ & $0,981 * * *$ & $0,764 * * *$ \\
\hline & średnie, secondary & $0,393 * * *$ & $0,510 * * *$ & $0,524 * * *$ & $0,294 * * *$ \\
\hline \multirow{2}{*}{$\begin{array}{l}\text { Aktywność zawodowa } \\
\text { (bierny-ref.), } \\
\text { Economic activity } \\
\text { (non-active - reference } \\
\text { category) }\end{array}$} & $\begin{array}{l}\text { pracujący/a, } \\
\text { employed }\end{array}$ & 0,053 & 0,088 & 0,106 & 0,097 \\
\hline & $\begin{array}{l}\text { bezrobotny/a, } \\
\text { unemployed }\end{array}$ & $-0,037$ & 0,190 & 0,144 & 0,099 \\
\hline
\end{tabular}


Tabela 4.

\begin{tabular}{|c|c|c|c|c|c|}
\hline \multirow{2}{*}{$\begin{array}{l}\text { Zmienna } \\
\text { Variable }\end{array}$} & \multirow{2}{*}{$\begin{array}{l}\text { Kategoria } \\
\text { Category }\end{array}$} & \multicolumn{2}{|c|}{ Mężczyźni Males } & \multicolumn{2}{|c|}{ Kobiety Females } \\
\hline & & 1950-1969 & 1970-1989 & $1950-1969$ & 1970-1989 \\
\hline \multirow{3}{*}{$\begin{array}{l}\text { Stan cywilny } \\
\text { (rozwiedziony/a-ref.), } \\
\text { Marital status (divorced } \\
\text { - reference category) }\end{array}$} & $\begin{array}{l}\text { kawaler/panna, } \\
\text { single }\end{array}$ & $-0,251$ & $-0,390$ & $0,700 * * *$ & 0,089 \\
\hline & $\begin{array}{l}\text { żonaty/zamężna, } \\
\text { married }\end{array}$ & $-0,217$ & 0,253 & 0,024 & $-0,319$ \\
\hline & $\begin{array}{l}\text { wdowiec/wdowa, } \\
\text { widowed }\end{array}$ & $-0,045$ & $-0,455$ & $-0,376$ & 0,479 \\
\hline \multicolumn{2}{|c|}{ Liczba dzieci, Number of children } & $-0,110$ & 0,002 & $-0,175^{*}$ & $-0,168$ \\
\hline \multicolumn{2}{|c|}{$\begin{array}{l}\text { Częstość praktyk religijnych, } \\
\text { Frequency of religious practices }\end{array}$} & $-0,009 * * *$ & $-0,007 * * *$ & $-0,007 * * *$ & $-0,010 * * *$ \\
\hline \multirow{3}{*}{$\begin{array}{l}\text { Stan cywilny*liczba } \\
\text { dzieci } \\
\text { (rozwiedziony/a*liczba } \\
\text { dzieci }- \text { ref.), } \\
\text { Marital status }{ }^{*} \text { number } \\
\frac{\text { of children }}{\text { (divorced }{ }^{*} \text { number of }} \\
\text { children - reference } \\
\text { category }\end{array}$} & $\begin{array}{l}\text { kawaler/panna* } \\
\text { liczba dzieci, single } \\
\text { *number of children }\end{array}$ & 0,289 & $-0,153$ & $-0,040$ & $-0,056$ \\
\hline & $\begin{array}{l}\text { żonaty/zamężna* } \\
\text { liczba dzieci, } \\
\text { married * number of } \\
\text { children }\end{array}$ & 0,064 & $-0,097$ & $-0,004$ & 0,133 \\
\hline & $\begin{array}{l}\text { wdowiec/wdowa* } \\
\text { liczba dzieci, } \\
\text { widowed*number of } \\
\text { children }\end{array}$ & & & $-0,104$ & $-0,551$ \\
\hline \multirow{2}{*}{$\begin{array}{l}\text { Miejsce zamieszkania* } \\
\text { liczba dzieci } \\
\text { (wieś*liczba dzieci } \\
\text { - ref.), } \\
\text { Place of } \\
\frac{\text { residence* number }}{\text { of children (rural }} \\
\text { area }{ }^{*} \text { number of children } \\
\text { - reference category) }\end{array}$} & $\begin{array}{l}\text { miasto pow. } 100 \text { tys } \\
* \text { liczba dzieci, town } \\
\text { of } 100,000 \text { and over } \\
* \text { number of children }\end{array}$ & $-0,090$ & 0,047 & $0,156^{* *}$ & $-0,250 * *$ \\
\hline & $\begin{array}{l}\text { miasto pon. } 100 \text { tys } \\
* \text { liczba dzieci, town } \\
\text { under } 100,000 * \\
\text { number of children }\end{array}$ & $-0,187$ & 0,033 & 0,097 & 0,065 \\
\hline \multicolumn{2}{|l|}{$\mathrm{N}$} & 3081 & 2928 & 4059 & 3476 \\
\hline \multicolumn{2}{|c|}{$\mathrm{R}^{2}$} & 0,072 & 0,077 & 0,116 & 0,093 \\
\hline
\end{tabular}

Źródło: Obliczenia własne na podstawie danych z GGS-PL-1. Krytyczny poziom istotności: $* * *<0,01 ; * *<0,05 ; *<0,1$

Source: Own calculations based on GGS-PL-1 data. Significance level: $* * *<0,01 ; * *<0,05$; $*<0,1$ 
Tabela 5. Wyniki estymacji modeli GLM zmiennej G1 dla mężczyzn i kobiet względem cech domu rodzinnego, kohorty urodzeniowe 1950-1969 i 1970-1989

Table 5. Estimation results of the G1-GLM models for males and females with parental home variables, birth cohorts of 1950-1969 and 1970-1989

\begin{tabular}{|c|c|c|c|c|c|}
\hline \multirow{2}{*}{$\begin{array}{l}\text { Zmienna } \\
\text { Variable }\end{array}$} & \multirow{2}{*}{$\begin{array}{l}\text { Kategoria } \\
\text { Category }\end{array}$} & \multicolumn{2}{|c|}{ Mężczyźni Males } & \multicolumn{2}{|c|}{ Kobiety Females } \\
\hline & & $1950-1969$ & $1970-1989$ & $1950-1969$ & $1970-1989$ \\
\hline \multicolumn{2}{|l|}{ Wiek, Age } & $-0,007$ & $0,040 * * *$ & $-0,033 * * *$ & $0,023 * * *$ \\
\hline \multirow{2}{*}{$\begin{array}{l}\text { Miejsce zamieszkania } \\
\text { w wieku } 15 \text { lat } \\
\text { (wieś - ref), } \\
\text { Place of residence at } \\
\text { age } 15 \\
\text { (rural area - reference } \\
\text { category) }\end{array}$} & $\begin{array}{l}\text { miasto pow. } 100 \text { tys., } \\
\text { town of } 100,000 \text { and } \\
\text { over }\end{array}$ & 0,001 & $0,584^{*}$ & $0,338^{*}$ & 0,163 \\
\hline & $\begin{array}{l}\text { miasto pon. } 100 \text { tys., } \\
\text { town under } 100,000\end{array}$ & 0,277 & 0,168 & $0,441 *$ & 0,077 \\
\hline \multirow{2}{*}{$\begin{array}{l}\text { Wykształcenie matki } \\
\text { (poniżej średniego - ref), } \\
\text { Mother's education } \\
\text { (below secondary } \\
\text { - reference category) }\end{array}$} & wyższe, tertiary & $1,461 * * *$ & $0,802 * * *$ & $1,495 * * *$ & $1,071 * * *$ \\
\hline & średnie, secondary & $0,363 * *$ & $0,593 * *$ & $0,381 * *$ & $0,528 * * *$ \\
\hline $\begin{array}{l}\text { Pracująca matka } \\
\text { (nie - ref.), } \\
\text { Mother at paid work } \\
\text { (non-working - reference } \\
\text { category) }\end{array}$ & tak, yes & $-0,528 * * *$ & 0,013 & $-0,032$ & $-0,241$ \\
\hline \multicolumn{2}{|c|}{ Liczba rodzeństwa, Number of siblings } & $-0,043^{*}$ & $-0,097 * * *$ & $-0,059 * *$ & $-0,104 * * *$ \\
\hline \multirow{2}{*}{$\begin{array}{l}\text { Znaczenie religii w domu } \\
\text { rodzinnym } \\
\text { (nieważne - ref.), } \\
\text { Value of religion } \\
\text { at parental home } \\
\text { (unimportant - reference } \\
\text { category) }\end{array}$} & ważne, important & $-0,874 * * *$ & $-0,676^{* * *}$ & $-0,670^{*}$ & $-1,019^{* * *}$ \\
\hline & $\begin{array}{l}\text { ani ważne, ani } \\
\text { nieważne, neither } \\
\text { important nor } \\
\text { unimportant }\end{array}$ & $-0,440$ & $-0,204$ & $-0,187$ & $-0,606^{* *}$ \\
\hline \multirow{2}{*}{$\begin{array}{l}\text { Pracująca matka*miejsce } \\
\text { zamieszkania w wieku } \\
15 \text { lat (niepracująca } \\
\text { matka*wieś - ref.), } \\
\text { Mother at paid work* } \\
\text { place of residence at age } \\
15 \text { (non-working mother } \\
\text { *rural area) }\end{array}$} & $\begin{array}{l}\text { pracująca matka } \\
\text { *miasto pow. } 100 \\
\text { tys., mother at paid } \\
\text { work * town of } \\
100,000 \text { and over }\end{array}$ & $0,505^{*}$ & $-0,008$ & 0,315 & 0,338 \\
\hline & $\begin{array}{l}\text { pracująca matka } \\
\text { *miasto pon. } 100 \\
\text { tys., mother at paid } \\
\text { work * town under } \\
100,000\end{array}$ & $0,672 * *$ & 0,265 & 0,198 & $0,559 *$ \\
\hline \multicolumn{2}{|l|}{$\mathrm{N}$} & 3023 & 2890 & 3974 & 3487 \\
\hline \multicolumn{2}{|l|}{$\mathrm{R}^{2}$} & 0,031 & 0,045 & 0,044 & 0,054 \\
\hline
\end{tabular}

Źródło: Obliczenia własne na podstawie danych z GGS-PL-1. Krytyczny poziom istotności: $* * *<0,01 ; * *<0,05 ; *<0,1$

Source: Own calculations based on GGS-PL-1 data. Significance level: ***<0,01; **<0,05; $*<0,1$ 
Tabela 6. Wyniki estymacji modeli GLM zmiennej G2 dla mężczyzn i kobiet względem cech domu rodzinnego, kohorty urodzeniowe 1950-1969 i 1970-1989

Table 6. Estimation results of the G2-GLM models for males and females with parental home variables, birth cohorts of 1950-1969 and 1970-1989

\begin{tabular}{|c|c|c|c|c|c|}
\hline \multirow{2}{*}{$\begin{array}{l}\text { Zmienna } \\
\text { Variable }\end{array}$} & \multirow{2}{*}{$\begin{array}{l}\text { Kategoria } \\
\text { Category }\end{array}$} & \multicolumn{2}{|c|}{ Mężczyźni Males } & \multicolumn{2}{|c|}{ Kobiety Females } \\
\hline & & $1950-1969$ & $1970-1989$ & $1950-1969$ & 1970-1989 \\
\hline \multicolumn{2}{|l|}{ Wiek, Age } & $-0,026 * * *$ & 0,008 & $-0,014 * *$ & 0,007 \\
\hline \multirow{2}{*}{$\begin{array}{l}\text { Miejsce zamieszkania } \\
\text { w wieku } 15 \text { lat (wieś-ref) } \\
\text { Place of residence at } \\
\text { age } 15 \\
\text { (rural area - reference } \\
\text { category) }\end{array}$} & $\begin{array}{l}\text { miasto pow. } 100 \text { tys., } \\
\text { town of } 100,000 \text { and } \\
\text { over }\end{array}$ & $0,466^{* *}$ & 0,320 & $0,882 * * *$ & 0,525 \\
\hline & $\begin{array}{l}\text { miasto pon. } 100 \text { tys., } \\
\text { town under } 100,000\end{array}$ & $0,285^{*}$ & 0,301 & 0,209 & 0,355 \\
\hline \multirow{2}{*}{$\begin{array}{l}\text { Wykształcenie matki } \\
\text { (poniżej średniego - ref) } \\
\text { Mother's education } \\
\text { (below secondary } \\
\text { - reference category) }\end{array}$} & wyższe, tertiary & $0,556^{* * *}$ & $0,549 * * *$ & $0,990 * * *$ & $0,624 * * *$ \\
\hline & średnie, secondary & $0,190 *$ & $0,326^{* * *}$ & $0,393 * * *$ & $0,550 * * *$ \\
\hline $\begin{array}{l}\text { Pracująca matka } \\
\text { (nie - ref.) } \\
\text { Mother at paid work } \\
\text { (non-working - reference } \\
\text { category) }\end{array}$ & tak, yes & $-0,043$ & $-0,048$ & $-0,130$ & 0,107 \\
\hline \multicolumn{2}{|c|}{ Liczba rodzeństwa, Number of siblings } & $-0,045 * * *$ & $-0,053^{*}$ & $-0,045 * * *$ & $-0,028$ \\
\hline \multirow{2}{*}{$\begin{array}{l}\text { Znaczenie religii w domu } \\
\text { rodzinnym } \\
\text { (nieważne - ref.), } \\
\text { Value of religion } \\
\text { at parental home } \\
\text { (unimportant - reference } \\
\text { category) }\end{array}$} & ważne, important & $-0,741 * * *$ & $-0,745^{* * *}$ & $-0,726 * * *$ & $-0,993 * * *$ \\
\hline & $\begin{array}{l}\text { ani ważne, ani } \\
\text { nieważne, neither } \\
\text { important nor } \\
\text { unimportant }\end{array}$ & $-0,164$ & $-0,291$ & $-0,179$ & $-0,154$ \\
\hline \multirow{2}{*}{$\begin{array}{l}\text { Pracująca matka*miejsce } \\
\text { zamieszkania w wieku } \\
15 \text { lat (niepracująca } \\
\text { matka*wieś - ref.), } \\
\text { Mother at paid work* } \\
\text { place of residence at age } \\
15 \text { (non-working mother } \\
\text { *rural area) }\end{array}$} & $\begin{array}{l}\text { pracująca matka } \\
* \text { miasto pow. } 100 \\
\text { tys., mother at paid } \\
\text { work * town of } \\
100,000 \text { and over }\end{array}$ & $-0,225$ & 0,160 & $-0,070$ & 0,342 \\
\hline & $\begin{array}{l}\text { pracująca matka } \\
\text { *miasto pon. } 100 \\
\text { tys., mother at paid } \\
\text { work * town under } \\
100,000\end{array}$ & $-0,067$ & 0,028 & $0,408 * *$ & $0,587 * * *$ \\
\hline \multicolumn{2}{|l|}{$\mathrm{N}$} & 3023 & 2890 & 3974 & 3487 \\
\hline \multicolumn{2}{|l|}{$\mathrm{R}^{2}$} & 0,044 & 0,054 & 0,079 & 0,077 \\
\hline
\end{tabular}

Źródło: Obliczenia własne na podstawie danych z GGS-PL-1. Krytyczny poziom istotności: $* * *<0,01 ; * *<0,05 ; *<0,1$

Source: Own calculations based on GGS-PL-1 data. Significance level: ***<0,01; **<0,05; $*<0,1$ 


\title{
SOCIO-ECONOMIC PREDICTORS OF WOMEN'S AND MEN'S VIEWS ON GENDER IN POLAND
}

\begin{abstract}
Fertility decline in developed countries over recent five decades and persisting low fertility in the remarkable number of countries are increasingly attributed to changing gender roles, particularly to incompatibilities between institutional adjustments of individual- and family- oriented institutions as well as within the family and changing perceptions on social roles of women and men. These arguments are voiced also when debating on low fertility in Poland. The article focuses on perceptions of gender roles and their diversity across population groups which differ by socio-demographic attributes. Additionally, possible influences of parental home on opinions about gender roles are accounted for.

The data coming from the Generations and Gender Survey, carried out in Poland in 2010/2011, made it possible to define two synthetic variables which described attitudes towards gender equality in the social sphere and in the private sphere (a responsibility for a child). Descriptive results confirmed findings of other studies: the gender attitudes are more diversified among women than men, especially as regards gender equality in the social sphere, women show more egalitarian attitudes than men, and within an age increase a social approval for gender equality declines.

The generalized linear mixed models of two synthetic gender variables were used to identify predictors of gender attitudes across two birth cohorts of women and men - those born either in the years 1950-1969 or in the years 1970-1989. Among individual characteristics education, religiosity and place of residence were found out - as expected - the main predictors of gender attitudes. Contrary to expectations, labour market status, marital status and a number of children did not always play a significant role for distinguished cohorts of men and women. Economic activity showed its impact on women's gender attitudes only. There are also some signs that in the 1970-1989 cohorts younger people are less in favour of gender equality than those over 30 years of age.

Parental home attributes (place of residence at age 15, mother' education and mother's economic acitivity, number of siblings, and religiosity) were displayed as relevant predictors of gender attitudes for both birth cohorts of men and women. However, paid work of a mother seemed to be a weaker predictor than expected.
\end{abstract}

Keywords: gender equality, gender attitudes, predictors of gender attitudes 